\section{Alternative to Avoid Tooth Discoloration after Regenerative Endodontic Procedure: A Systematic Review}

\author{
Luciane Geanini Pena dos Santos ${ }^{1}$, Luiz Alexandre Chisini ${ }^{1}$, Camila Guerner \\ Springmann², Beatriz Dulcineia Mendes de Souza², Fernanda Geraldo \\ Pappen ${ }^{1}$, Flávio Fernando Demarco ${ }^{1}$, Mara Cristina Santos Felippe ${ }^{2}$, Wilson \\ Tadeu Felippe ${ }^{2}$
}

'Graduate Program in Dentistry, UFPel - Universidade Federal de Pelotas, Pelotas, RS, Brazil ${ }^{2}$ Department of Dentistry, UFSC - Universidade Federal de Santa Catarina, Florianópolis, SC, Brazil

Correspondence: Flávio Fernando Demarco, Rua Gonçalves Chaves, 457, $5^{\circ}$ andar, CEP 96015-560 Pelotas, RS, Brazil. Tel.: +55-53-3222-6690. e-mail: ffdemarco@gmail.com

\begin{abstract}
This systematic review aimed to evaluate whether alternative materials to conventional triple antibiotic paste (TAP - metronidazole, ciprofloxacin, and minocycline) and grey mineral trioxide aggregate (GMTA) could avoid tooth discoloration in teeth submitted to Regenerative Endodontic Procedure (REP). It was also investigated if dental bleaching is able to reverse the color of darkened teeth due to REP. The search was conducted in four databases (Medline via PubMed, Scopus, ISI Web of Science and BVS - Virtual health library), following the Preferred Reporting Items for Systematic Reviews and Meta-Analyses. The retrieved papers were uploaded in the software EndNote ${ }^{\mathrm{TM}}$ and two reviewers independently selected the studies and extracted the data. Only studies in humans (case reports, case series, clinical trials) were included in the review. From 1,122 potentially eligible studies, 83 were selected for full-text analysis, and 38 were included in the review. The included studies were mainly case reports $(76.3 \%)$. The studies described a total of 189 teeth submitted to REP. From these, about 54\% of teeth presented some degree of discoloration. Most teeth presenting color alteration were treated with TAP, especially when combined with GMTA. Only three studies performed dental bleaching to restore the color of teeth and neither bleaching technique was able to restore the original color of the crowns. The use of alternative materials to TAP and GMTA, such as double antibiotic paste or $\mathrm{Ca}(\mathrm{OH})_{2}$ pastes and white mineral trioxide aggregate or Biodentine ${ }^{\mathrm{TM}}$, reduces the occurrence of tooth discoloration.
\end{abstract}

Key Words: dental pulp, disinfection, regenerative endodontics, tooth discoloration, triple antibiotic paste.

\section{Introduction}

Regenerative endodontic procedure (REP) has been proposed as a treatment option for necrotic immature permanent teeth (NIPT) in detriment to apexogenesis with calcium hydroxide $\left(\mathrm{CaOH}_{2}\right)$ and apexification with trioxide mineral aggregate (MTA) (1). REP is based on the formation of blood clot into the root canal space creating a natural scaffold that serves as anchorage site for cells from apical papilla and periodontal tissues. Additionally, blood supplies growth factors that act along with those from dentin matrix, contributing to the formation of a new tissue into the pulp cavity and to the resumption of root development $(1,2)$. Therefore, REP seems to provide an increase in root lengthening and thickening, as well as a remission of the signs and symptoms of apical periodontitis (2).

In the Clinical Considerations for a Regenerative Procedure, the American Association of Endodontists (AAE) (3) recommends for root canal disinfection the use of $\mathrm{CaOH}_{2}$ or triple antibiotic paste (TAP - metronidazole, ciprofloxacin and minocycline), for a short period (3). Probably, the presence of minocycline, an antibiotic of tetracycline family, in TAP composition plays an important role in tooth discoloration $(4,5)$. Minocycline binds to the calcium ions present in the dentin by means of chelation, being incorporated into the dentin matrix and inducing a change in the color of the dental structure (4). To avoid crown discoloration, it was proposed to seal the coronal dentinal tubules with bonding agent prior to the use of TAP as intracanal medication (6) as well as the replacement or eliminating minocycline from TAP composition. The alternatives to minocycline report in the literature are performed mainly with cefaclor (7), amoxicillin (8) or clindamicine (9). Some studies have adopted only the elimination of minocycline of conventional TAP, so called Double antibiotic paste (DAP - metronidazole, ciprofloxacin) $(10,11)$.

Moreover, the blood clotted inside of the root canal must be protected in its cervical portion by a sealing material, conventionally the MTA (2). However, MTA also can lead to a change in the tooth color due to presence of minerals as bismuth oxide, its radiopacifier component (12). Although the AAE recommends the use of glass ionomer cement (GIC) to avoid the discoloration in areas where esthetic is primordial (3), several studies have performed the seal with 
white MTA (WMTA) due to less amount of metallic ions $(7,13,14)$, which could reduce tooth crown discoloration.

Therefore, although satisfactory biological results are achieved after REP $(1,2,15)$, several case reports have indicated color change, especially in those cases treated with TAP (16-18). A recent literature review (19) has also shown that TAP is the main reason to tooth discoloration in REP, although did not directly compare the possible reduction of tooth discoloration when alternatives materials (to TAP and gray MTA) are employed. Thus, it suggest that the use of pastes alternative to TAP and the replacement of grey MTA (GMTA) could decrease the percentage of tooth discoloration $(5,20,21)$. Moreover, in cases of discoloration, dental bleaching can be performed aiming to minimize esthetic damages. However, the ability of dental bleaching in restore the original color of teeth did not was aim of systematic reviews. Similarly, little is investigated to ability of alternatives materials to TAP and GMTA to avoid the tooth discoloration in REP. Thus, the aim of this study was to review the literature systematically and evaluate whether alternatives to conventional TAP and GMTA could avoid tooth discoloration in teeth submitted to revascularization and investigate if dental bleaching is $\vec{s}$ able to reverse the color of discolored teeth due to REP.

\section{Material and Methods}

This systematic review was carried out according to the guidelines of Cochrane Handbook for Systematic Reviews of Interventions, following the four-phase flow diagram of the Preferred Reporting Items for Systematic Reviews and Meta-Analyses (PRISMA) (22). This report is based on the PRISMA Statement. The question of research was adapted from the PICO framework; Population - human immature permanent teeth; Intervention and Comparison - use of TAP and GMTA in regenerative endodontic procedures vs. alternative materials; Outcome - tooth discoloration.

A structured research was carried in Pubmed/Medline, Scopus, ISI Web of Science and BVS - Virtual health library. Date limit was set up to March 2017, with no language restriction. The search and the combinations of syntaxes are described in Table 1. The references of all eligible papers were also hand-searched. A wide search strategy was used to avoid missing information. Duplicated studies were removed by using EndNote ${ }^{\mathrm{TM}} \mathrm{X} 7$ software (Thomson Reuters, Rochester, New York, NY, USA). The inclusion criteria were in vivo original studies (prospective, retrospective, clinical cases, case series, clinical trials) in which regenerative procedures were performed in immature permanent teeth, and which color maintenance or the tooth discoloration, as an outcome or not, were described. Studies were included independently of their follow-up intervals. The exclusion criteria were: reviews, in vitro studies, studies in animals, or studies that did not report the color maintenance or tooth discoloration.

Two independent reviewers (L. A. C. and C. G. S.) initially screened the titles of all identified studies. If the title indicated possible inclusion, the abstract was carefully appraised, and the manuscripts considered eligible for the review (or in case of doubt) were selected for full-text reading. Discrepancies were resolved by discussion with a third reviewer (L. G. P.) Standardized outline was used for data extraction of the studies that met the inclusion criteria. Due to the high heterogeneity of included studies, evaluation of risk of bias and meta-analysis could not be performed. Consequently, the characteristics of studies were summarized descriptively.

\section{Results}

\section{Studies selection}

The flowchart of the systematic review is shown in Figure 1. A total of 1,122 records were identified and 843 remained after duplicated studies removal. After title and abstract evaluation, 83 papers were selected for full-text assessment. From these, 38 studies met the inclusion criteria of the present study. Forty-five studies were excluded after full-text reading once they did not report the color maintenance or the tooth discoloration (23-62), or since the tooth discoloration described had occurred prior to revascularization procedure (63-68).

\section{Studies Characteristics}

Most included papers were case reports (76.3\%) followed by case series (15.8\%). Few clinical trials were included $(69,70)$. The first published study included in this review was issued in 2009 (71). The studies were conducted in 14 different countries; most of them were carried out in the United States of America (29\%) followed by Turkey (13\%) (Table 2). The included studies described

Table 1. Structured search strategy carried out in MEDLINE/PubMed database* $^{*}$

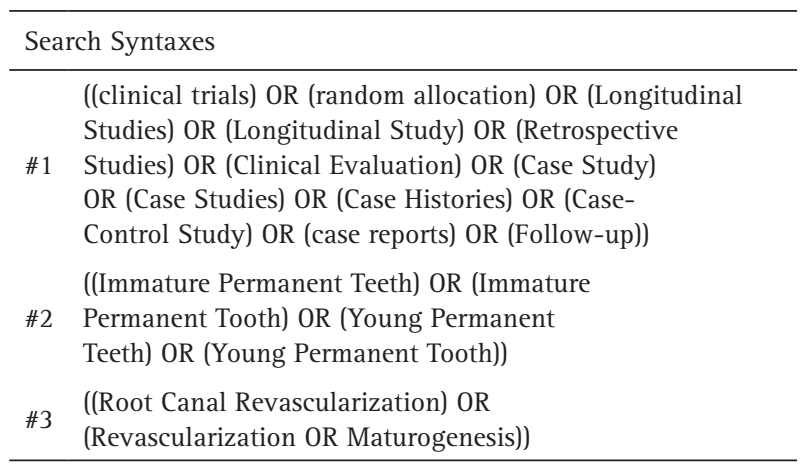

* Searches in SciVerse Scopus ${ }^{\circledR}$ (SS), ISI web of a science ${ }^{\circledR}$ andCochrane library ${ }^{\circledR}$ were adapted according to the database. In ISI web of a science ${ }^{\circledR}$, the search \#5 was included also keyword: (AND Dentistry) 
the regenerative procedures performed in a total of 189 teeth. From these, $81 \%(n=153)$ were incisors, $17 \%(n=33)$ premolar, $1 \%$ molars $(n=2)$, and $0.5 \%(n=1)$ canine.

Triple antibiotic paste (TAP) in different concentrations were used as intracanal medication in $23.3 \%$ of the teeth $(n=44)$. Alternative pastes to TAP, were used in $65.6 \%$ of teeth $(n=124)$. From these, minocycline were replaced by cefaclor in 72 cases $(6,7,70,72,73)$, amoxicillin in 18 $(8,74)$, clindamicine in 31 teeth $(9)$, and tetracycline in one (75). Double antibiotic paste (DAP - metronidazole, ciprofloxacin) were used in two cases $(10,11)$. In 10.6\% of the teeth $(n=20), \mathrm{Ca}(\mathrm{OH})_{2}$ was used as intracanal medication $(14,69,76-81)$, and in $0.5 \%$ of the teeth $(n=01)$ no medication was applied (13).

Regarding the cervical sealing material, grey MTA (GMTA) was employed in $50.8 \%$ of the teeth $(n=96)(4,8-$ $11,16,71,73-75,80-86)$, white MTA $(6,7,13,14,18,69,70,76-$ $78,87-95)$ in $46.0 \%(n=87)$, Biodentine $(72)$ in $2,1 \%$ $(\mathrm{n}=04)$ and Calcium-enriched mixture (CEM) (79) cement in $1 \%(n=02)$. Although, it was not a goal of this study to review the means by which dental color was taken, it was noticed that in all the included studies teeth color analysis was performed only by means of visual parameters. Spectrophotometers or colorimeters were not used for this propose in the included studies.

\section{Synthesis of Results}

Considering the 189 teeth evaluated, 54\% ( $n=102)$ presented some degree of discoloration. Tooth color assessment was performed at the end of REP, therefore the evaluated teeth had already suffered the possible effects of intracanal medication as well as cervical sealing material. Thus, the results of the present review are described according the association of these factors: (1) TAP/GMTA, (2) TAP/alternative materials (AM) to GMTA (WMTA, Biodentine, and CEM), (3) AM to TAP/GMTA, and (4) AM to TAP/ AM to GMTA.

From the 14 teeth treated with TAP/GMTA association, 13 (92.9\%) showed tooth discoloration $(4,16,71,82-86)$; while, from de 30 teeth treated with TAP/AM to GMTA, 21 (70.0\%) presented crown discoloration $(18,69,87-95)$. When AM to TAP were associated with GMTA, 45 teeth (54.9\%)

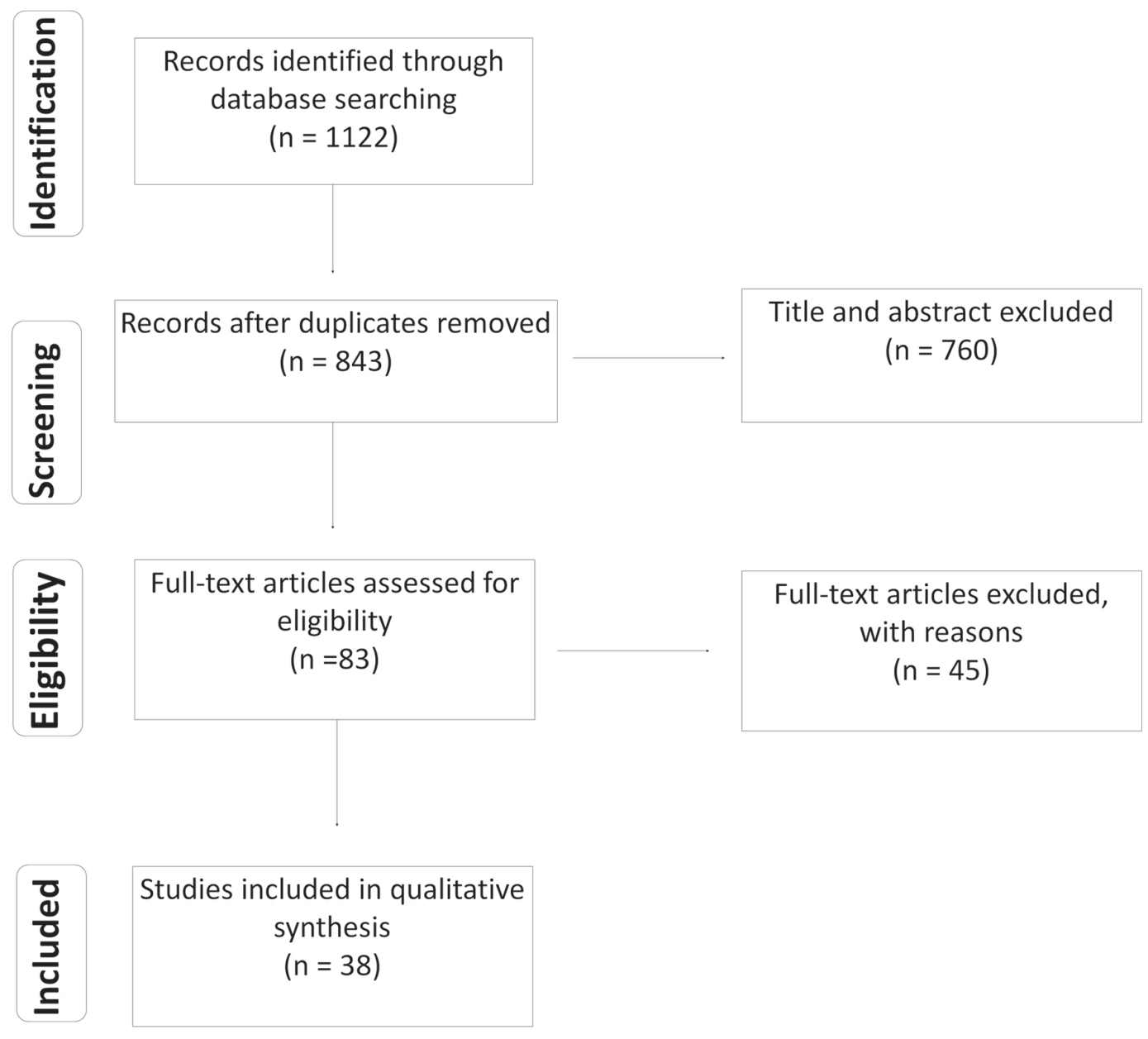

Figure 1. Flow diagram. 


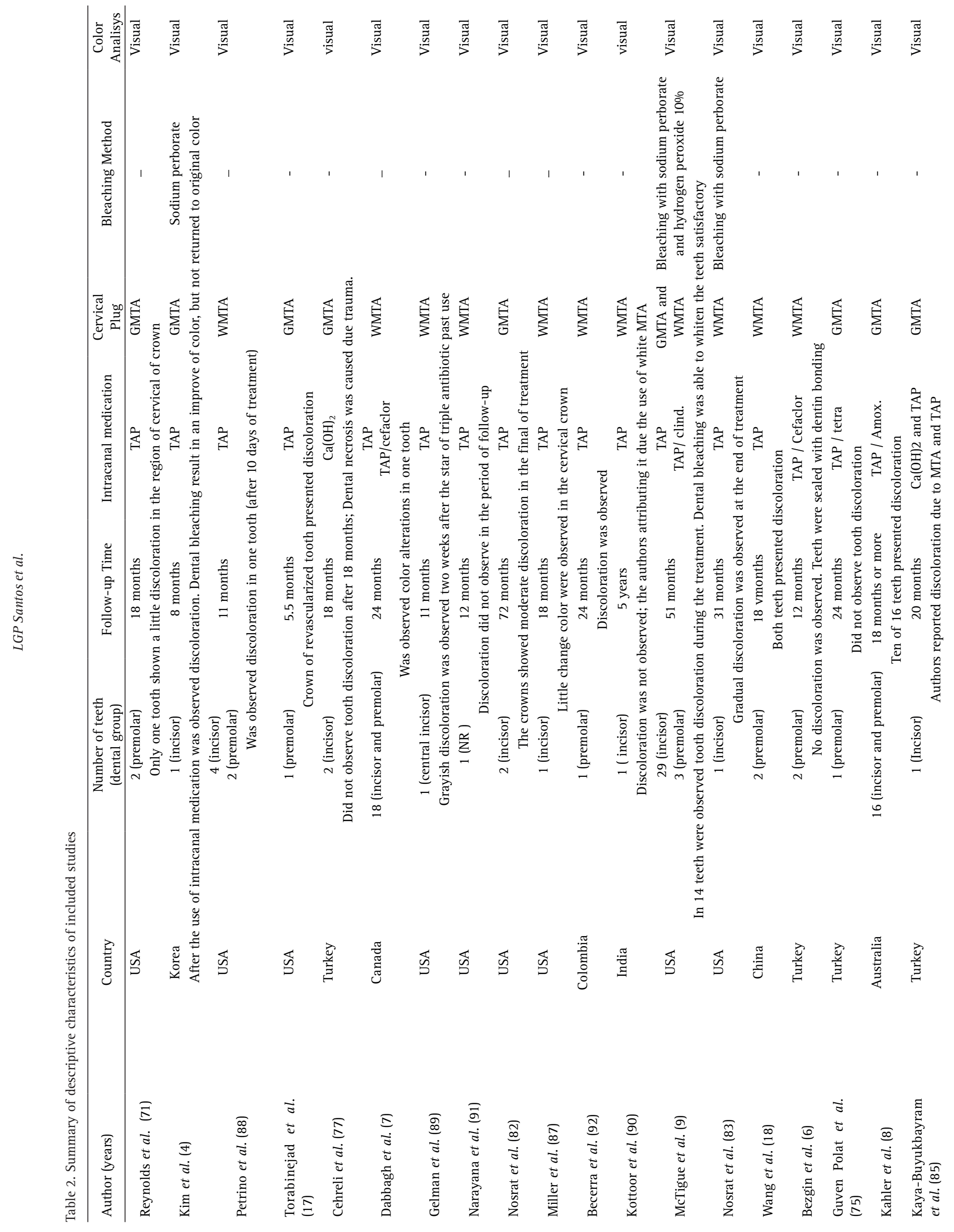




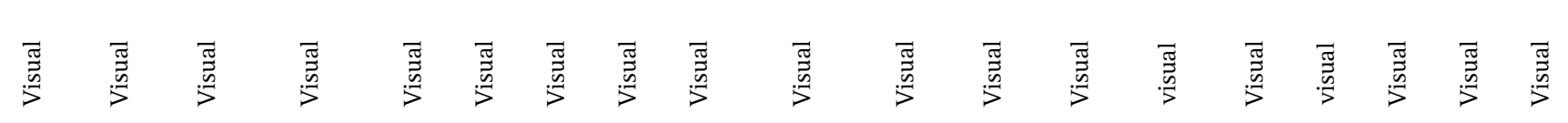

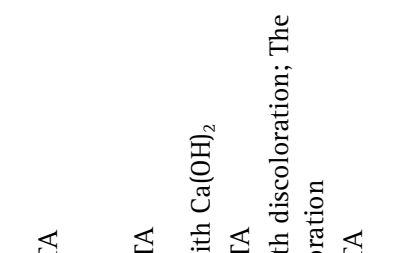

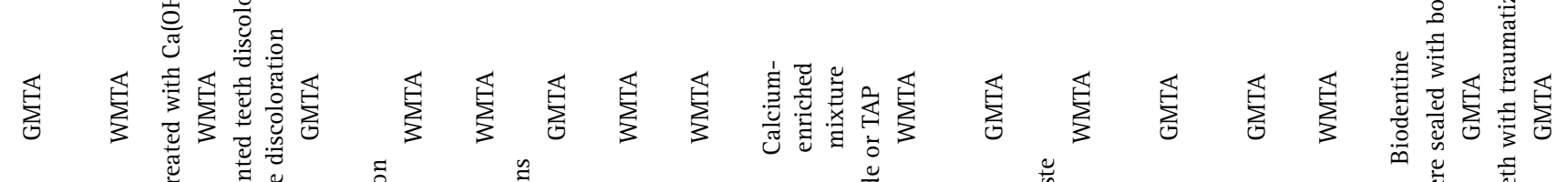

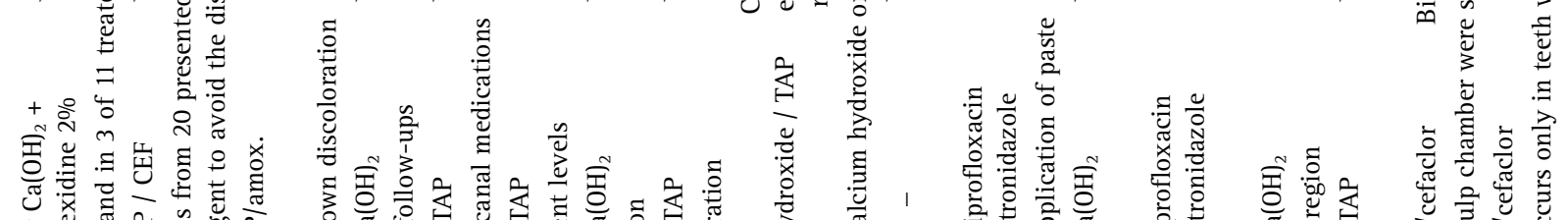

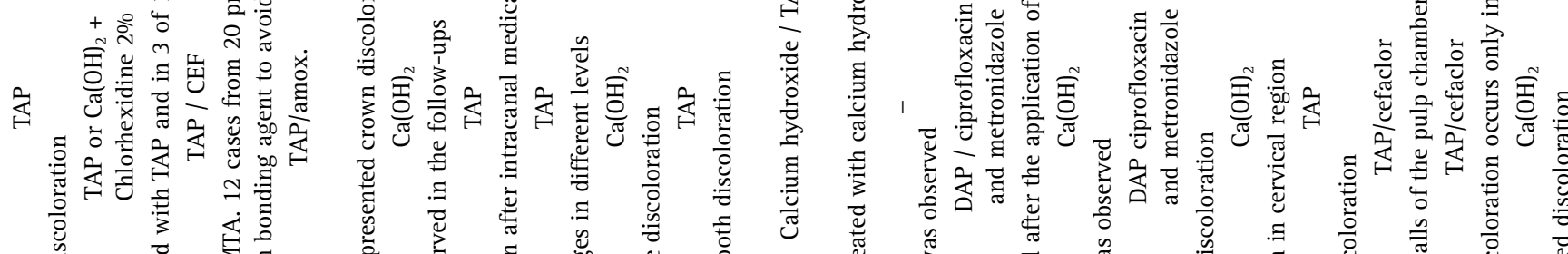

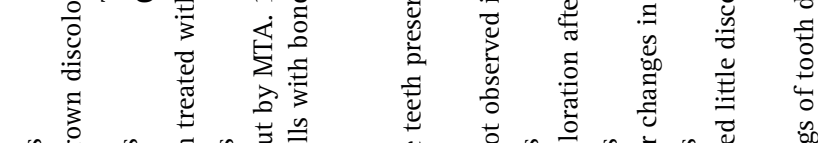

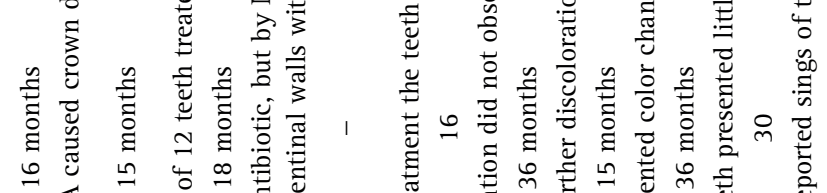

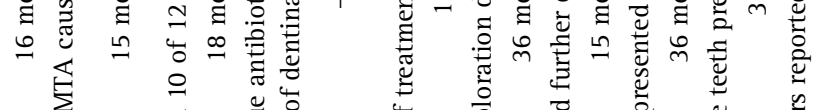

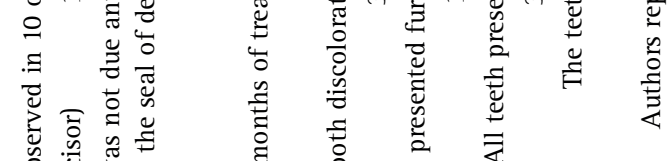

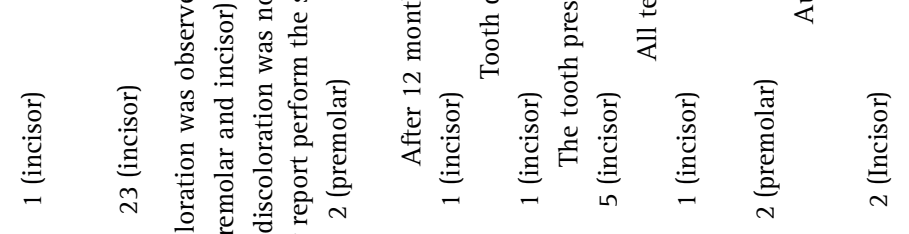

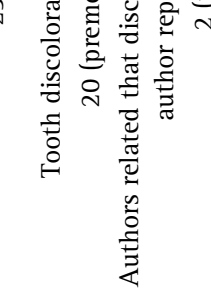

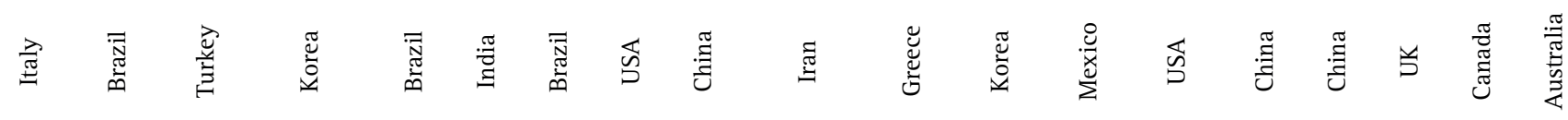

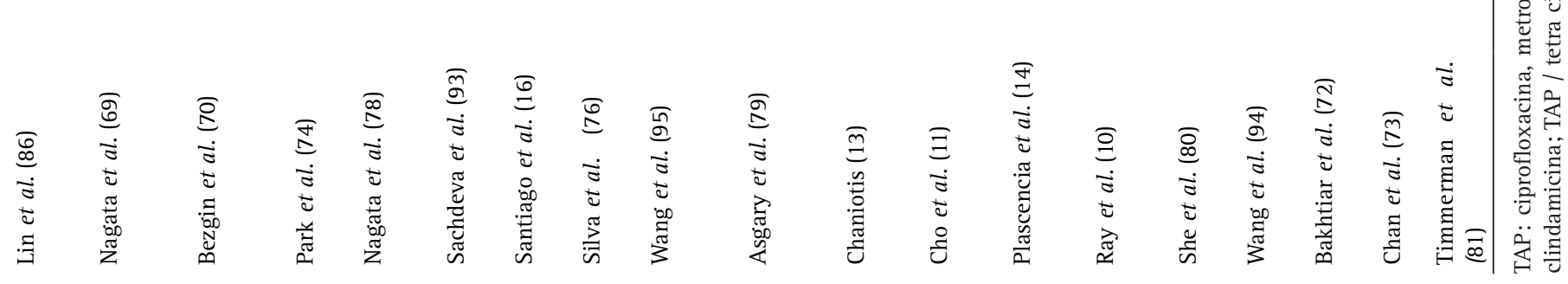


presented color change $(8-11,73-75,80,81)$. Considering the 63 teeth treated with AM to TAP/AM to GMTA, 21 (33.3\%) presented crown discoloration $(6,7,13,14,69,70,72,76-79)$. Thus, a tendency to avoid dental color alterations in studies that employed alternative materials (to TAP and GMTA) is observed in the Figure 2.

Moreover, we observed few studies that followed the strategy advised by AAE for avoid discoloration, sealing pulp chamber walls with dentin bonding agent. Bezgin et al. (6) applying this strategy observed no dentin discoloration in both two revascularized teeth; while, Bakhtiar et al. (72) observed minimal discoloration in all teeth sealed with dentin bonding.

In three studies dental bleaching was performed in 16 teeth $(4,9,83)$ to restore the natural dental color. Internal bleaching technique applying sodium perborate as whitening agent was employed in two studies (2 teeth). The third study, associated 10\% hydrogen peroxide to the sodium perborate (83). In studies in which only sodium perborate was used, authors described an improvement in the color of the teeth, but teeth do not return to the original shade. Satisfactory results were reported for 11 of the 14 teeth treated with sodium perborate associated

\section{$\vec{s}$ with hydrogen peroxide.}

\section{Discussion}

\& $\quad$ The regeneration of NIPT is a recent approach presenting promissory results $(1,2)$. However, the risk of tooth discoloration, observed in several cases $(10,16,18,69,87,89,92,94)$, can compromise esthetic results and even the quality of life of the individuals (96). In the present study, the literature was systematically reviewed to assess whether alternative materials to conventional
TAP and GMTA could avoid tooth discoloration after pulp revascularization. The included studies showed that there is great potential for tooth discoloration after REP. More than $50 \%$ of the revascularized teeth presented some color alteration, mainly when TAP was used as intracanal medication and GMTA as cervical sealing material.

TAP is the most used intracanal medication in revascularization (2), presenting biocompatibility (97) and adequate antimicrobial capacity, being able to perform root canal system disinfection (98-100). According to the American Association of Endodontics (AAE) antibiotic pastes should be used at concentrations ranging from $0.1 \mathrm{mg} /$ $\mathrm{mL}$ to $1 \mathrm{mg} / \mathrm{mL}$, which promote low cytotoxicity to stem cells from apical papilla (3), maintaining its disinfection ability (101). However, even nowadays, authors have still employed pastes at different concentrations higher than that recommended. A recent case series study reported the use of $1 \mathrm{~g} / \mathrm{mL}$ on detriment to recommended due to clinical difficulties of applying pastes in low concentrations (72). Hence, crown discoloration has been more frequently reported after the use of $1 \mathrm{~g} / \mathrm{mLTAP}$ in root canal treatment. Some studies reports a rapid tooth discoloration after TAP application $(89,93)$. The main reason for tooth staining (69), has been advocated to minocycline, a tetracycline derivate, present in TAP composition (102). Discoloration induced by minocycline normally occurs in the first 24 hours after its use, promoting a bluish-grey staining, clinically perceivable (11). Usually, this alteration is more evident in tooth crown, and in the cervical third of the root (102). Therefore, modifications to the original TAP (98) have been proposed, with the aim at avoiding discoloration, by the use of cefaclor $(6,7,70,72,73)$, amoxicillin $(8,74)$ and clindamicine instead of minocycline (9) Nevertheless,

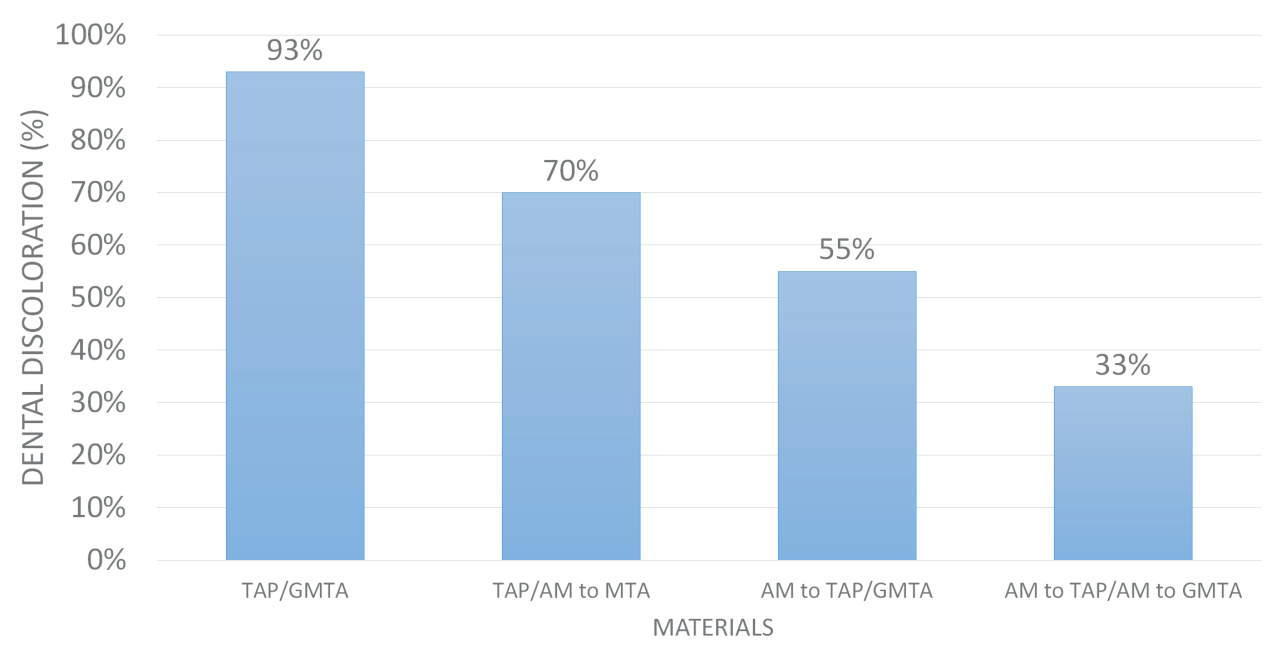

Figure 2. Tooth discoloration according with materials used to regenerative endodontic treatment. 
some degree of discoloration has been still observed after the use these alternative medications. Dabbagh et al. (7) associating WMTA to TAP/cefaclor observed discoloration in only one of the 18 revascularized teeth. An in vitro study showed that TAP with minocycline promoted higher discoloration than TAP with amoxicillin, doxycycline, or cefaclor (102). It was also observed that TAP induced a severe color change in the first day of the assessment, while the use of amoxicillin showed similar discoloration only after one week. On the other hand, double antibiotic paste (DAB - metronidazole and ciprofloxacin) and $\mathrm{Ca}(\mathrm{OH})_{2}$ did not produced color alterations (102). Another in vitro study showed similar discolorations induced by these pastes, while the most esthetic outcomes were found when alternatives to minocycline were used (5).

A reduced number of cases reporting discoloration were observed when $\mathrm{Ca}(\mathrm{OH})_{2}$ was applied as intracanal medication, however, from 20 teeth revascularized with $\mathrm{Ca}(\mathrm{OH})_{2}$ six presented some color change $(14,69,76-81)$. This may be explained by the fact that the materials used in the cervical plug can also promote discoloration, especially GMTA $(80,81)$. Although in some cases is difficult to define if the color change was promote by antibiotic paste.

GMTA has been extensively used as cervical sealing material, being applied above the blood clot in resvacularized teeth (2). However, GMTA presents high levels of iron, magnesium, aluminum, as well as bismuth oxideas a radiopacifier, which can oxidize promoting tooth discoloration (12). Staining due to MTA can occur immediately after the first day of application and increase over the time (21). Aiming to avoid tooth discoloration, WMTA was developed, with significant reduction of minerals in its composition. Despite this, in vitro studies have shown that WMTA also could promote some degree of discoloration $(20,21)$.

Only one study included in this review used Biodentine ${ }^{\mathrm{TM}}$ as cervical plug. As a result, all teeth treated showed minimal discoloration (72). In these cases, the color alteration probably can be attributed to the biochemical interaction between Biodentine $\mathrm{T}^{\mathrm{TM}}$ and platelet-rich fibrin (PRF), mixed to the blood clot, since Biodentine presents zirconium oxide as radiopacifier instead of bismuth oxide $(20,21)$. Biodentine ${ }^{\mathrm{T} M}$ was recently developed tricalcium silicatebased material, which presents high biocompatibility and mechanical resistance (103). Recently, in order to avoid the negative effect of the Portland cement-based materials on tooth color, AAE (3) recommends the use of glass ionomer cement in the cervical sealing, especially for the anterior teeth, in which esthetics assumes an important role. No study included in this review used GIC for this purpose.

Another reported way to minimize the risks of tooth discoloration is sealing dentinal tubules of the pulp chamber with adhesive agent prior to the use of TAP (3). However, more studies are necessary to confirm the role of adhesive agents in prevent color alterations following REP. In the present review, three studies performed this preventive technique $(6,70,72)$. Bezgin et al. (6) applying adhesive agent previously intracanal medication with TAP/ cefaclor, followed by WMTA as cervical sealing material. No discoloration was observed in both two evaluated teeth. However, in a study performed in 20 cases of revascularization, the application of an adhesive agent before TAP/cefaclor, did not prevent discoloration in 12 teeth. Nevertheless, the staining was attributed to the GMTA, used as cervical sealing material (70). Finally, Bakhtiar et al. (72) also sealed coronal dentinal tubules prior to treat root canal with TAP/cefaclor; however, as cervical sealing material Biodentine ${ }^{\mathrm{TM}}$ was used rather MTA. Discoloration occurred in all the four revascularized teeth. Authors attributed the staining to the interaction between Biodentine and PRF. Confirming the results of those studies, an in vitro (4) one observed that the use of the adhesive (self-etching, 2-component adhesive dentin bonding system) reduced, but did not prevent staining. The samples became yellow, reproducing the color of minocycline. The explanation for this was probably due the use of a clear bonding agent, without the ability of completely blocking the yellowish color of the antibiotic. Besides, it is important highlight that the REP per se can promote some degree of discoloration. An recent in vitro study that evaluate by spectrophotometry the change color in teeth submitted to REP observed a low discoloration in the control group - no antibiotic pastes treatment (5).

Aiming restore tooth color, some studies reported perform dental bleaching. The crowns were treated by the internal bleaching technique with sodium perborate or sodium perborate associated to hydrogen peroxide $(4,9,83)$. However, neither technique was able to restore the original color of the crowns. These results did not corroborate with a study that used spectrophotometer, before and after the use of materials commonly applied in REP, to investigate the efficacy of dental bleaching on the color of bovine teeth. The results showed that only one application of 10\% carbamide peroxide, inside the pulp chamber and on the outer surface of the crown, was enough to make the color of the teeth similar to the original one (5).

In all the studies included in this review, the visual method of analysis was used to evaluate the color change. However, this method results in a subjective evaluation, which can be affected by factors such as the experience and the chromatic perception of the evaluator, the illumination of the environment (104). In order to avoid biases resulting from the evaluation of the human eye, spectrophotometers should be used instead. Spectrophtometer devices 
determine the color of the tooth from numerical values that represent light and hue, being considered reliable methods for color reading (105). However, these devices are not yet widely used in the clinical routine.

It is important to highlight that reports of tooth discoloration was found predominantly in cases treated with TAP and GMTA. Although the high amount of studies found at the initial search, many studies did not fulfill inclusion criteria of this review. Therefore, the present results should be interpreted with caution. Since the main outcome assessed in included studies was the survival of the teeth, dental color was mostly reported as secondary data. Therefore, tooth discoloration might had been underestimate, being reported only in those cases in which a major color change was noticed. Moreover, the lonely effect of the different materials involved in REP on tooth discoloration is a very hard task, since intracanal medication and cervical sealing are applied sequentially, and both have potential to induce tooth color alteration. The conduction of randomized clinical trials evaluating tooth color on each phase of regenerative endodontics is highly recommended to better understand the role of each material in tooth discoloration.

Alternatives to conventional Triple Antibiotic Pastes and Gray MTA avoid tooth discoloration in teeth submitted to revascularization. The association of alternatives to Triple Antibiotic Paste and alternatives to Gray MTA resulted in minor discoloration. Dental bleaching is able to reverse partially the color of discolored teeth due to REP. Minocycline seems to be the main responsible for discoloration induced by TAP.

\section{Resumo}

Esta revisão sistemática teve como objetivo avaliar se materiais alternativos à pasta tri-antibiótica convencional (TAP, em Inglês - metronidazol, ciprofloxacina e minociclina) e ao agregado trióxido mineral cinza (MTA cinza) poderiam evitar a descoloração dentária em dentes submetidos ao procedimento endodôntico regenerativo (REP, em Inglês). Também foi investigado se o clareamento dental é capaz de reverter a cor dos dentes escurecidos devido ao REP. A busca foi realizada em quatro bases de dados (Medline via PubMed, Scopus, ISI Web of Science e BVS - Biblioteca Virtual de Saúde), seguindo os Principais Itens para Relatar Revisões Sistemáticas e Meta-análises. Os artigos obtidos foram carregados no software EndNoteTM e dois revisores independentes selecionaram os estudos e extrairam os dados. Apenas estudos em humanos (relatos de casos, séries de casos, ensaios clínicos) foram incluídos na revisão. De 1.122 estudos potencialmente elegiveis, 83 foram selecionados para análise do artigo completo, e 38 foram incluídos na revisão. Os estudos incluídos foram principalmente relatos de casos $(76,3 \%)$. Os estudos descreveram um total de 189 dentes submetidos ao REP. Destes, cerca de 54\% dos dentes apresentaram algum grau de descoloração. A maioria dos dentes com alteração de cor foi tratada com TAP, principalmente quando combinada com MTA-cinza. Apenas três estudos realizaram o clareamento dental para restaurar a cor dos dentes e nem a técnica de clareamento conseguiu restaurar a cor original das coroas. 0 uso de materiais alternativos à TAP e ao MTA cinza, como a pasta bi-antibiótica, pasta de $\mathrm{Ca}(\mathrm{OH}) 2$ e MTA branco ou BiodentineTM, reduz a ocorrência de descoloração dentária.

\section{References}

1. Chisini LA, Grazioli G, Francia A, San Martin AS, Demarco, FF, Conde MCM. Revascularization versus apical barrier technique with mineral trioxide aggregate plug: A systematic review. G Ital Endod 2018;32:916.

2. Conde MC, Chisini LA, Sarkis-Onofre R, Schuch HS, Nor JE, Demarco FF. A scoping review of root canal revascularization: relevant aspects for clinical success and tissue formation. Int Endod J 2017;50:860-874.

3. American Association of Endodontists. Endodontists' Guide to CTD 2017. Available from: https://www.aae.org/specialty/wp-content/ uploads/sites/2/2017/07/aae_2017guidetocdt.pdf. Latests access: October 15, 2018.

4. Kim JH, Kim Y, Shin SJ, Park JW, Jung IY. Tooth discoloration of immature permanent incisor associated with triple antibiotic therapy: a case report. J Endod 2010;36:1086-91.

5. Santos LG, Felippe WT, Souza BD, Konrath AC, Cordeiro MM, Felippe MC. Crown discoloration promoted by materials used in regenerative endodontic procedures and effect of dental bleaching: spectrophotometric analysis. J Appl Oral Sci 2017;25:234-42.

6. Bezgin T, Yilmaz AD, Çelik BN, Sönmez H. Concentrated platelet-rich plasma used in root canal revascularization: 2 case reports. Int Endod J 2014;47:41-49.

7. Dabbagh B, Alvaro E, Vu DD, Rizkallah J, Schwartz S. Clinical Complications in the Revascularization of Immature Necrotic Permanent Teeth. Ped Dent 2012;34:414-417.

8. Kahler B, Mistry S, Moule A, Ringsmuth AK, Case P, Thomson A, et al. Revascularization outcomes: A prospective analysis of 16 consecutive cases. J Endod 2014;40:333-338.

9. McTigue DJ, Subramanian K, Kumar A. Management of immature permanent teeth with pulpal necrosis: A case series. Ped Dent 2013;35:55-60.

10. Ray HL, Jr., Marcelino J, Braga R, Horwat R, Lisien M, Khaliq S. Longterm follow up of revascularization using platelet-rich fibrin. Dent Traumatol 2016;32:80-84.

11. Cho WC, Kim MS, Lee HS, Choi SC, Nam OH. Pulp revascularization of a severely malformed immature maxillary canine. J Oral Sci 2016;58:295298.

12. Parirokh $M$, Torabinejad $M$. Mineral trioxide aggregate: a comprehensive literature review--Part I: chemical, physical, and antibacterial properties. J Endod 2010;36:16-27.

13. Chaniotis $A$. The use of a single-step regenerative approach for the treatment of a replanted mandibular central incisor with severe resorption. Int Endod J 2016;49:802-812.

14. Plascencia $H$, Cruz $A$, Diaz $M$, Jimenez $A L$, Solis $R$, Bernal C. Root canal filling after revascularization/revitalization. J Clin Pediatr Dent 2016;40:445-449.

15. Chisini LA, Conde MC, Alcazar JC, Silva AF, Nor JE, Tarquinio SB, et al. Immunohistochemical expression of TGF-beta1 and osteonectin in engineered and $\mathrm{Ca}(\mathrm{OH})_{2}$-repaired human pulp tissues. Braz Oral Res 2016;30:e93.

16. Santiago CN, Pinto SS, Sassone LM, Hirata R, Jr., Fidel SR. Revascularization technique for the treatment of external inflammatory root resorption: a report of 3 cases. J Endod 2015;41:1560-1564.

17. Torabinejad $M$, Turman M. Revitalization of tooth with necrotic pulp and open apex by using platelet-rich plasma: A case report. J Endod 2011;37:265-268.

18. Wang HJ, Chen YHM, Chen KL. Conservative treatment of immature teeth with apical periodontitis using triple antibiotic paste disinfection. J Dent Sci 2013;11:196-211.

19. Kahler B, Rossi-Fedele G. A review of tooth discoloration after regenerative endodontic therapy. J Endod 2016;42:563-9.

20. Kohli MR, Yamaguchi M, Setzer FC, Karabucak B. Spectrophotometric analysis of coronal tooth discoloration induced by various bioceramic cements and other endodontic materials. J Endod 2015;41:1862-6.

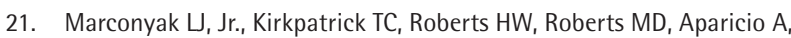
Himel VT, et al. A Comparison of coronal tooth discoloration elicited by various endodontic reparative materials. J Endod 2016;42:470-473.

22. Moher D, Liberati A, Tetzlaff J, Altman DG, Group P. Preferred 
reporting items for systematic reviews and meta-analyses: the PRISMA statement. PLoS Med 2009;6:e1000097.

23. Al-Ghamdi NS, Al-Nazhan S. Pulp revascularization of immature maxillary first premolar. J Conserv Dent 2015;18:496-499.

24. Atabek D, Sillelioglu H, Cinar C, Olmez A. Maturogenesis of an early erupted immature permanent tooth: a case report with 7-year followup. J Clin Pediatr Dent 2015;39:262-267.

25. Meschi N, Hilkens P, Lambrichts I, Van den Eynde K, Mavridou A, Strijbos 0 , et al. Regenerative endodontic procedure of an infected immature permanent human tooth: an immunohistological study. Clin Oral Investig 2016;20:807-814.

26. Miltiadous ME, Floratos SG. Regenerative endodontic treatment as a retreatment option for a tooth with open apex - a case report. Braz Dent J 2015;26:552-556.

27. Aldakak MM, Capar ID, Rekab MS, Abboud S. Single-visit pulp revascularization of a nonvital immature permanent tooth using Biodentine. Iran Endod J 2016;11:246-249.

28. El Ashiry EA, Farsi NM, Abuzeid ST, El Ashiry MM, Bahammam HA. Dental pulp revascularization of necrotic permanent teeth with immature apices. J Clin Pediatr Dent 2016;40:361-366.

29. Estefan BS, El Batouty KM, Nagy MM, Diogenes A. Influence of age and apical diameter on the success of endodontic regeneration procedures. J Endod 2016;42:1620-1625.

30. Farhad AR, Shokraneh A, Shekarchizade N. Regeneration or replacement? A case report and review of literature. Dent Traumatol 2016;32:71-79

31. Zizka R, Buchta $T$, Voborna I, Harvan L, Sedy J. Root maturation in teeth treated by unsuccessful revitalization: 2 case reports. J Endod 2016:42:724-729.

32. Lucisano MP, Nelson-Filho P, Silva LA, Silva RA, de Carvalho FK, de Queiroz AM. Apical revascularization after delayed tooth replantation: an unusual case. case rep dent 2016;2016:2651643.

33. Priya MH, Tambakad PB, Naidu J. Pulp and periodontal regeneration of an avulsed permanent mature incisor using platelet-rich plasma after delayed replantation: a 12-month clinical case study. J Endod 2016:42:66-71.

34. Subash D, Shoba K, Aman S, Bharkavi SK. Revitalization of an immature permanent mandibular molar with a necrotic pulp using platelet-rich fibrin: a case report. J Clin Diagn Res 2016;10:ZD21-ZD3.

35. Topcuoglu G, Topcuoglu HS. Regenerative endodontic therapy in a single visit using platelet-rich plasma and biodentine in necrotic and asymptomatic immature molar teeth: A report of 3 cases. J Endod 2016;42:1344-1346.

36. Zhujiang A, Kim SG. Regenerative endodontic treatment of an immature necrotic molar with arrested root development by using recombinant human platelet-derived growth factor: a case report. J Endod 2016;42:72-75.

37. Al-Tammami MF, Al-Nazhan SA. Retreatment of failed regenerative endodontic of orthodontically treated immature permanent maxillary central incisor: a case report. Restor Dent Endod 2017;42:65-71.

38. Silujjai J, Linsuwanont P. Treatment outcomes of apexification or revascularization in nonvital immature permanent teeth: $\mathrm{A}$ Retrospective Study. J Endod 2017;43:238-245.

39. Banchs F, Trope M. Revascularization of immature permanent teeth with apical periodontitis: New treatment protocol? J Endod 2004;30:196-200.

40. Thibodeau B, Trope M. Pulp revascularization of a necrotic infected immature permanent tooth: case report and review of the literature. Pediatr Dent 2007;29:47-50.

41. Cotti E, Mereu M, Lusso D. Regenerative treatment of an immature, traumatized tooth with apical periodontitis: Report of a case. J Endod 2008;34:611-616

42. Jung IY, Lee SJ, Hargreaves KM. Biologically based treatment of immature permanent teeth with pulpal necrosis: a case series. J Endod 2008;34:876-887.

43. Shin SY, Albert JS, Mortman RE. One step pulp revascularization treatment of an immature permanent tooth with chronic apical abscess: a case report. Int Endod J 2009;42:1118-1126.

44. Cehreli ZC, Isbitiren B, Sara S, Erbas G. Regenerative endodontic treatment (revascularization) of immature necrotic molars medicated with calcium hydroxide: A case series. J Endod 2011;37:1327-1330.

45. Aggarwal V, Miglani S, Singla M. Conventional apexification and revascularization induced maturogenesis of two non-vital, immature teeth in same patient: 24 months follow up of a case. J Conserv Dent 2012;15:68-72.

46. Chen MYH, Chen KL, Chen CA, Tayebaty F, Rosenberg PA, Lin LM. Responses of immature permanent teeth with infected necrotic pulp tissue and apical periodontitis/abscess to revascularization procedures. Int Endod JI 2012;45:294-305.

47. Jadhav G, Shah N, Logani A. Revascularization with and without platelet-rich plasma in nonvital, immature, anterior teeth: a pilot clinical study. J Endod 2012;38:1581-7.

48. Jeeruphan $T$, Jantarat J, Yanpiset $K$, Suwannapan L, Khewsawai $P$, Hargreaves KM. Mahidol study 1: comparison of radiographic and survival outcomes of immature teeth treated with either regenerative endodontic or apexification methods: a retrospective study. J Endod 2012;38:1330-1336.

49. Kim DS, Park HJ, Yeom JH, Seo JS, Ryu GJ, Park KH, et al. Long-term follow-ups of revascularized immature necrotic teeth: three case reports. Int J Oral Sci 2012;4:109-113.

50. Lenzi R, Trope M. Revitalization procedures in two traumatized incisors with different biological outcomes. J Endod 2012;38:411-414.

51. Rudagi KB, Rudagi BM. One-step apexification in immature tooth using grey mineral trioxide aggregate as an apical barrier and autologus platelet rich fibrin membrane as an internal matrix. J Conserv Dent 2012;15:196-199.

52. Shimizu E, Jong G, Partridge N, Rosenberg PA, Lin LM. Histologic observation of a human immature permanent tooth with irreversible pulpitis after revascularization/regeneration procedure. J Endod 2012;38:1293-1297.

53. Farsi N, Abuzeid S, El Ashiry E. Revascularization of dental pulp in human necrotic permanent teeth with immature apex: Three case reports. Life Sci J 2013;10:1516-1521.

54. Forghani M, Parisay I, Maghsoudlou A. Apexogenesis and revascularization treatment procedures for two traumatized immature permanent maxillary incisors: a case report. Restor Dent Endod 2013:38:178-181.

55. Jadhav G, Shah N, Logani A. Comparative outcome of revascularization in bilateral, non-vital, immature maxillary anterior teeth supplemented with or without platelet rich plasma: A case series. J Conserv Den 2013;16:568-572.

56. Kalaskar RR, Kalaskar AR. Maturogenesis of non-vital immature permanent teeth. Contemp Clin Dent 2013;4:268-270

57. Martin G, Ricucci D, Gibbs JL, Lin LM. Histological findings of revascularized/revitalized immature permanent molar with apical periodontitis using platelet-rich plasma. J Endod 2013;39:138-144.

58. Paryani K, Kim SG. Regenerative endodontic treatment of permanent teeth after completion of root development: A report of 2 cases. $J$ Endod 2013;39:929-934.

59. Soares AD, Lins FF, Nagata JY, Gomes B, Zaia AA, Ferraz CCR, et al. Pulp revascularization after root canal decontamination with calcium hydroxide and 2\% chlorhexidine gel. J Endod 2013;39:417-420.

60. Chandran V, Chacko V, Sivadas G. Management of a nonvital young permanent tooth by pulp revascularization. Int J Clin Pediatr Dent 2014;7:213-216.

61. Raju SM, Singhyadav S, Ramakumar M. Revascularization of immature mandibular premolar with pulpal necrosis - a case report. J Clin Diagn Res 2014;8:ZD29-ZD31.

62. McCabe P. Revascularization of an immature tooth with apical periodontitis using a single visit protocol: A case report. Int Endod J 2015;48:484-497.

63. Shah N, Logani A, Bhaskar U, Aggarwal V. Efficacy of revascularization to induce apexification/apexogensis in infected, nonvital, immature teeth: a pilot clinical study. J Endod 2008;34:919-925; Discussion 1157.

64. Ding RY, Cheung GSP, Chen J, Yin XZ, Wang QQ, Zhang CF. Pulp revascularization of immature teeth with apical periodontitis: a clinical study. J Endod 2009;35:745-749.

65. Shivashankar VY, Johns DA, Vidyanath S, Ramesh Kumar M. Platelet rich 
fibrin in the revitalization of tooth with necrotic pulp and open apex. J Conserv Dent 2012:15:395-398.

66. Abduljabbar F, Bakhsh A, Abed H. Revascularization procedure induced maturogenesis of upper permanent incisor. Oral Health Dent Manag 2014;13:831-834.

67. Jadhav GR, Shah N, Logani A. Platelet-rich plasma supplemented revascularization of an immature tooth associated with a periapical lesion in a 40-year-old man. Case Rep Dent 2014;2014:479584.

68. Solomon RV, Faizuddin U, Guniganti SS, Waghray S. Analysis of the rate of maturogenesis of a traumatized Cvek's stage 3 anterior tooth treated with platelet-rich fibrin as a regenerative tool using threedimensional cone-beam computed tomography: An original case report. Indian J Dent Res 2015;26:90-95.

69. Nagata JY, Figueiredo De Almeida Gomes BP, Rocha Lima TF, Murakami $L S$, De Faria $D E$, et al. Traumatized immature teeth treated with 2 protocols of pulp revascularization. J Endod 2014;40:606-12.

70. Bezgin T, Yilmaz AD, Celik BN, Kolsuz ME, Sonmez H. Efficacy of Platelet-rich Plasma as a Scaffold in Regenerative Endodontic Treatment. J Endod 2015;41:36-44.

71. Reynolds K, Johnson JD, Cohenca N. Pulp revascularization of necrotic bilateral bicuspids using a modified novel technique to eliminate potential coronal discolouration: a case report. Int Endod J 2009;42:84-92.

72. Bakhtiar H, Esmaeili S, Fakhr Tabatabayi S, Ellini MR, Nekoofar MH, Dummer PM. Second-generation platelet concentrate (platelet-rich fibrin) as a scaffold in regenerative endodontics: a case series. J Endod 2017:43:401-408.

73. Chan EK, Desmeules M, Cielecki M, Dabbagh B, Ferraz Dos Santos B. Longitudinal cohort study of regenerative endodontic treatment for immature necrotic permanent teeth. J Endod 2017;43:395-400.

74. Park HB, Lee BN, Hwang YC, Hwang IN, Oh WM, Chang HS. Treatment of non-vital immature teeth with amoxicillin-containing triple antibiotic paste resulting in apexification. Restor Dent Endod 2015;40:322-327.

75. Guven Polat G, Yildirim C, Akgun OM, Altun C, Dincer D, Ozkan CK. The use of platelet rich plasma in the treatment of immature tooth with periapical lesion: a case report. Restor Dent Endod 2014;39:230-234.

76. Silva MHC, Campos CN, Coelho MS. Revascularization of an immature tooth with apical periodontitis using calcium hydroxide: A 3-year follow-up. Open Dent J 2015;9:482-5

77. Cehreli ZC, Sara S, Aksoy B. Revascularization of immature permanent incisors after severe extrusive luxation injury. J Can Dent Assoc $2012 ; 78$.

78. Nagata JY, Rocha-Lima TF, Gomes BP, Ferraz CC, Zaia AA, Souza-Filho FJ, et al. Pulp revascularization for immature replanted teeth: A case report. Aus Dent J 2015;60:416-420.

79. Asgary S, Fazlyab M, Nosrat A. Regenerative endodontic treatment versus apical plug in immature teeth: three-year follow-up. J Clin Pediatr Dent 2016;40:356-360.

80. She CM, Cheung GS, Zhang CF. Long-term follow-up of a revascularized immature necrotic tooth evaluated by CBCT. Case Rep Dent 2016;2016:4982458.

81. Timmerman A, Parashos P. Delayed root development by displaced mineral trioxide aggregate after regenerative endodontics: a case report. J Endod 2017;43:252-256.

82. Nosrat A, Homayounfar N, Oloomi K. Drawbacks and unfavorable outcomes of regenerative endodontic treatments of necrotic immature teeth: A literature review and report of a case. J Endod 2012;38:14281434.

83. Nosrat A, Li KL, Vir K, Hicks ML, Fouad AE. Is Pulp Regeneration Necessary for Root Maturation? J Endod 2013;39:1291-1295.

84. Torabinejad M, Turman M. Revitalization of Tooth with Necrotic Pulp and Open Apex by Using Platelet-rich Plasma: A Case Report Reply. J Endod 2011;37:743-744.

85. Kaya-Buyukbayram I, Ozalp S, Aytugar E, Aydemir S. Regenerative endodontic treatment of an infected immature dens invaginatus with the aid of cone-beam computed tomography. Case Rep Dent
2014:2014:403045.

86. Lin LM, Shimizu E, Gibbs JL, Loghin S, Ricucci D. Histologic and histobacteriologic observations of failed revascularization/ revitalization therapy: a case report. J Endod 2014:40:291-295.

87. Miller EK, Lee JY, Tawil PZ, Teixeira FB, Vann Jr WF. Emerging therapies for the management of traumatized immature permanent incisors. Ped Dent 2012;34:66-69.

88. Petrino JA, Boda KK, Shambarger S, Bowles WR, McClanahan SB. Challenges in Regenerative Endodontics: A Case Series. J Endod 2010;36:536-541.

89. Gelman R, Park H. Pulp revascularization in an immature necrotic tooth: a case report. Pediatr Dent 2012;34:496-499.

90. Kottoor J, Velmurugan N. Revascularization for a necrotic immature permanent lateral incisor: A case report and literature review. Int J Paediatr Dent 2013;23:310-316.

91. Narayana P, Hartwell GR, Wallace R, Nair UP. Endodontic clinical management of a dens invaginatus case by using a unique treatment approach: A case report. J Endod 2012;38:1145-1148.

92. Becerra P, Ricucci D, Loghin S, Gibbs JL, Lin LM. Histologic study of a human immature permanent premolar with chronic apical abscess after revascularization/revitalization. J Endod 2013;40:133-139.

93. Sachdeva GS, Sachdeva LT, Goel M, Bala S. Regenerative endodontic treatment of an immature tooth with a necrotic pulp and apical periodontitis using platelet-rich plasma (PRP) and mineral trioxide aggregate (MTA): a case report. Int Endod J 2015;48:902-910.

94. Wang $\mathrm{H}$, Chen YM, K C. Conservative treatment of immature teeth with apical periodontitis using triple antibiotic paste disinfection. J Dent Sci 2016;11:196-201.

95. Wang $Y, Z$ Zhu $X F$, Zhang CF. Pulp revascularization on permanent teeth with open apices in a middle-aged patient. J Endod 2015;41:15711575.

96. Klages U, Erbe C, Sandru S, Brullman D, Wehrbein h. Psychosocial impact of dental aesthetics in adolescence: validity and reliability of a questionnaire across age-groups. Qual Life Res 2015;24:379-390.

97. Gomes-Filho JE, Duarte PCT, De Oliveira CB, Watanabe S, Lodi CS, Cintra LTA, et al. Tissue reaction to a triantibiotic paste used for endodontic tissue self-regeneration of nonvital immature permanent teeth. J Endod 2012;38:91-94

98. Hoshino E, Kurihara-Ando N, Sato I, Uematsu H, Sato M, Kota K, et al. In-vitro antibacterial susceptibility of bacteria taken from infected root dentine to a mixture of ciprofloxacin, metronidazole and minocycline. Int Endod J 1996;29:125-130.

99. Sato I, Ando-Kurihara N, Kota K, Iwaku M, Hoshino E. Sterilization of infected root-canal dentine by topical application of a mixture of ciprofloxacin, metronidazole and minocycline in situ. Int Endod J 1996;29:118-124.

100. Thibodeau B, Teixeira F, Yamauchi M, Caplan DJ, Trope M. Pulp revascularization of immature dog teeth with apical periodontitis. J Endod 2007;33:680-689.

101. Ruparel NB, Teixeira FB, Ferraz CC, Diogenes A. Direct effect of intracanal medicaments on survival of stem cells of the apical papilla. J Endod 2012;38:1372-5.

102. Akcay $M$, Arslan $H$, Yasa B, Kavrik F, Yasa E. Spectrophotometric analysis of crown discoloration induced by various antibiotic pastes used in revascularization. J Endod 2014;40:845-848.

103. Laurent P, Camps J, De Meo M, Dejou J, About I. Induction of specific cell responses to a $\mathrm{Ca}(3) \mathrm{SiO}(5)$-based posterior restorative material. Dent Mater 2008;24:1486-1494.

104. Yap AU, Sim CP, Loh WL, Teo JH. Human-eye versus computerized color matching. Oper Dent 1999;24:358-363.

105. Chisini LA, Conde MCM, Meireles SS, Dantas RVF, Sarmento HR, Della Bona A, Corrêa MB, Demarco FF. Effect of temperature and storage time on dental bleaching effectiveness. J Esthet Restor Dent 2018;1-5.

Received February 13, 2018 Accepted May 11, 2018 